\title{
PENERAPAN STRATEGI PEMBELAJARAN EVERY ONE IS TEACHER HERE UNTUK MENINGKATKAN KEMAMPUAN PEMECAHAN MASALAH MATERI PERBANDINGAN PADA SISWA KELAS VII SMP ISLAM FATAHILLAH SINGOSARI TAHUN PELAJARAN 2017/2018
}

\author{
Septia Nurcahyani \\ Program Studi Pendidikan Matematika FKIP Universitas Islam Malang \\ Email: septia.nurcahyani@yahoo.com.
}

\begin{abstract}
Abstrak
Penelitian ini bertujuan untuk mendeskripsikan penerapan stategi pembelajaran Every One is Teacher Here untuk meningkatkan kemampuan pemecahan masalah materi perbandingan pada siswa kelas VII SMP Islam Fatahillah Singosari tahun pelajaran 2017/2018. Dari hasil penelitian, disimpulkan bahwa stategi pembelajaran Every One is Teacher Here untuk meningkatkan kemampuan pemecahan masalah, dengan langkah-langkah pembelajaran: (1) Membuat kartu pertanyaan, (2) Shake and answer a card question (mengacak dan menjawab kartu pertanyaan), (3) Presentasi individual, dan (4) penutup. Deskripsi peningkatan dari siklus I ke II: (1) persentase ketuntasan keberhasilan tes akhir siklus I mencapai $68,18 \%$, sedangkan pada siklus II mencapai $81,82 \%$ (2) keterlaksanaan pembelajaran guru pada siklus I mencapai $88,97 \%$ dengan taraf keberhasilan dapat dikategorikan sangat baik dan pada siklus II mencapai 93,62\% dengan taraf keberhasilan dapat dikategorikan sangat baik (3) kegiatan siswa siklus I mencapai 79,55\% dengan taraf keberhasilan dapat dikategorikan baik dan pada siklus II mencapai $86,32 \%$ dengan taraf keberhasilan dapat dikategorikan sangat baik (4) hasil wawancara siswa pada siklus I mencapai 66,66\% dengan 4 dari 6 siswa menyatakan senang dengan stategi pembelajaran Every One is Teacher Here. Pada siklus II hasil wawancara siswa juga mencapai 83,33\% dengan 5 dari 6 siswa menyatakan senang dengan model pembelajaran yang diterapkan.
\end{abstract}

Kata-kata kunci: penerapan, Every One is Teacher Here, pemecahan masalah.

\section{PENDAHULUAN}

Pendidikan merupakan proses mendidik yang di dalamnya terkandung proses komunikasi antara yang mendidik dan yang dididik, sehingga dapat mengembangkan pengetahuan (kognitif), sikap (afektif), dan keterampilan (psikomotor) peserta didik. Pada kurikulum 2013 ini, siswa dituntut untuk lebih aktif dan kreatif dalam proses pembelajaran di sekolah, khususnya pada pelajaran matematika yang memerlukan banyak pemahaman konsep tentang materi-materi yang sedang diajarkan.

Matematika merupakan salah satu bidang studi yang harus dikuasai oleh siswa untuk memecahkan permasalahan sehari-hari. Banyak siswa bahkan orang dewasa berpikir bahwa matematika merupakan bidang studi yang paling sulit, karena matematika merupakan subjek yang ideal untuk mengembangkan pola pikir anak di usia dini sampai yang sudah berada di bangku kuliah. 
Untuk itu berbagai upaya telah dilakukan untuk meningkatkan hasil belajar siswa di sekolah, antara lain dengan perbaikan mutu belajar mengajar yang terencana. Dengan adanya perencanaan belajar mengajar di sekolah yang baik akan mendukung keberhasilan pengajaran. Dengan demikian usaha perencanaan pengajaran yang baik diupayakan agar siswa memiliki kemampuan yang maksimal untuk meningkatkan kemampuan komunikasi dan hasil belajar siswa terutama pada pembelajaran matematika, sehingga dapat memenuhi harapan yang baik bagi guru dan siswanya. Dalam hal ini pelajaran matematika merupakan salah satu pelajaran yang di ujinasionalkan untuk lulus dari suatu sekolah baik tingkat SD, SMP, maupun SMA, sehingga siswa wajib menguasai pelajaran matematika minimal nilai mencapai Kriteria Ketuntasan Minimal (KKM).

Menurut Ariana, (2014:2) kemampuan pemecahan masalah merupakan hal yang penting, karena kemampuan peserta didik dalam memecahkan masalah dapat mendorong kemampuan peserta didik untuk berfikir kritis, logis dan kreatif. Dalam matematika, kemampuan pemecahan masalah merupakan kemampuan dalam menyelesaikan soal cerita, soal tidak rutin, dan mengaplikasikan matematika dalam kehidupan sehari-hari atau keadaan lain. Jika kemampuan pemecahan masalah peserta didik rendah, maka peserta didik tidak akan terampil dalam memilih kondisi, konsep yang relevan, mencari generalisasi, merumuskan rencana penyelesaian serta mengorganisasikan keterampilan yang sudah di milikinnya

Salah satu masalah dalam pembelajaran matematika adalah rendahnya kemampuan pemecahan masalah. Rendahnya kemampuan pemecahan masalah matematika peserta didik disebabkan karena ketika peserta didik menyelesaikan suatu permasalahan matematika hanya didasarkan pada cara praktis, sehingga peserta didik tidak benar-benar memahami materi dan sistematika penyelesaian. Menurut Polya (dalam Nirmalitasi, 2010:2) dalam memecahkan suatu masalah matematika terdapat empat langkah yang harus dilakukan, yaitu: (1) memahami masalah, (2) merencanakan pemecahannya, (3) menyelesaikan masalah sesuai dengan rencana langkah ke dua, dan (4) memeriksa kembali hasil yang diperoleh (looking back). Dalam menyelesaikan satu permasalahan matematika dibutuhkan suatu konsep baru yang diharapkan bisa meningkatkan pemahaman dan pembelajaran untuk bisa menyelesaikan permasalahan secara sistematis yang pada akhirnya akan meningkatkan kemampuan pemecahan masalah matematika peserta didik.

Menurut pengamatan peneliti pada saat melaksanakan observasi di SMP Islam Fatahillah, ada hal-hal yang perlu diperhatikan dalam pembelajaran matematika di kelas. Seperti pada saat guru menerangkan materi di depan kelas, hanya beberapa peserta didik yang mengamati dan mau mendengarkan. Namun tidak dapat dipungkiri, bahwa rendahnya kemampuan pemecahan masalah peserta didik untuk aktif dalam proses pembelajaran matematika di kelas tidak sepenuhnya disebabkan oleh diri peserta didik saja, namun dari strategi dan model pembelajaran di kelas yang diterapkan oleh guru kurang menarik perhatian peserta didik, sehingga peserta didik merasa malas dan kurang aktif dalam proses pembelajaran di kelas. Pembelajaran matematika di kelas selama ini hampir sepenuhnya berpusat pada guru matematika dengan menggunakan strategi ceramah dan penugasan saja. Untuk mengetahui kemampuan pemecahan masalah peserta didik, peneliti membagikan soal tes kepada peserta didik. Dan setelah soal tes dikerjakan oleh peserta didik dianalisis, ternyata terlihat bahwa kemampuan pemecahan masalah peserta didik sangat rendah. Dalam menjawab soal yang diberikan, peserta didik masih belum dapat memberikan jawaban yang tepat. Dari 22 peserta didik 
hanya 8 peserta didik yang dapat menyelesaikan soal tes. Sehingga berdasarkan nilai tes yang sudah dikerjakan hanya $36,36 \%$ peserta didik yang memenuhi kriteria tes kemampuan pemecahan masalah

Berdasarkan uraian di atas, maka alasan peneliti akan berupaya mengimplementasikannya dengan judul penerapan strategi pembelajaran Every One is Teacher Here untuk meningkatkan kemampuan pemecahan masalah materi perbandingan pada siswa kelas VII SMP Islam Fatahillah Singosari tahun pelajaran 2017/2018.

Berdasarkan konteks dan fokus penelitian di atas, maka rumusan masalah dalam penelitian ini "Bagaimanakah penerapan strategi pembelajaran Every One is Teacher Here untuk meningkatkan kemampuan pemecahan masalah materi perbandingan pada siswa kelas VII SMP Islam Fatahillah?”.

Sesuai dengan rumusan masalah di atas, tujuan penelitian ini untuk mendeskripsikan penerapan stategi pembelajaran Every One is Teacher Here untuk meningkatkan kemampuan pemecahan masalah materi perbandingan pada siswa kelas VII SMP Islam Fatahillah Singosari.

Menurut Sodiq (2001:21), strategi Every One is Teacher Here yaitu strategi yang dapat digunakan untuk meningkatkan proses pembelajaran siswa dan dapat disesuaikan dengan tujuan yang ingin dicapai oleh pembelajaran pada berbagai mata pelajaran, khususnya pencapaian tujuan yaitu meliputi aspek: kemampuan mengemukakan pendapat, kemampuan menganalisa masalah, kemampuan menuliskan pendapat-pendapatnya (kelompoknya) setelah melakukan pengamatan, kemampuan menyimpulkan, dan lain-lain.

Menurut Sudjana (1989:24) strategi pembelajaran Everyone is Teacher Here adalah salah satu strategi dalam strategi pembelajaran aktif (Active Learning). "Strategi pembelajaran Everyone is Teacher Here adalah strategi pembelajaran yang digunakan oleh pendidik dengan maksud meminta peserta didik untuk semuanya berperan menjadi narasumber terhadap semua temannya di kelas belajar"

Silberman (2009:183) memaparkan langkah-langkah penerapan strategi Everyone is Teacher Here adalah sebagai berikut:

1) Guru membagikan kartu kosong kepada setiap siswa. Guru meminta para siswa menulis sebuah pertanyaan tentang materi pelajaran yang sedang dipelajari.

2) Guru mengumpulkan kartu, mengocok dan membagikan satu pada setiap siswa. Guru meminta siswa membaca pertanyaan yang ada pada kartu dan memikirkan jawaban.

3) Guru memanggil peserta didik yang akan membaca dengan keras kartu yang mereka dapat dan menjawab pertanyaan yang diterimanya.

4) Guru meminta kepada siswa yang lain untuk menambahkan jawaban yang diberikan.

5) Guru melanjutkan ke siswa lain bila waktu masih memungkinkan

Pemecahan masalah adalah serangkaian oprasi mental yang dilakukan seseorang untuk mencapai suatu tujuan tertentu baik pemecahan maasalah rutin mupun pemecahan masalah non-rutin. Pemecahan masalah juga merupakan serangkaian oprasi mental yang dilakukan seseorang untuk mencapai suatu tujuan tertentu.

\section{METODE PENELITIAN}

Pendekatan yang digunakan dalam penelitian ini adalah kualitatif dan kuantitatif, sedangkan jenis penelitiannya adalah penelitian tindakan kelas (classroom action 
research). Penelitian ini dilakukan di SMP Islam Fatahillah yang berada di Jl. Kandangan Nomor 14 Kecamatan Singosari Kabupaten Malang 65153. Adapun subyek penelitian ini adalah peserta didik kelas VII SMP Islam Fatahillah Singosari yang berjumlah 22 siswa.

Adapun teknik pengumpulan data dalam penelitian ini dilakukan dengan: (1) wawancara, digunakan untuk mendapatkan informasi lebih mendalam tentang keadaan kelas tersebut yang dilakukan sebelum penelitian, (2) soal tes, menggunakan soal tes tulis dalam bentuk uraian yang disesuaikan dengan indikator kemampuan pemecahan masalah, dan (3) pedoman wawancara.

Instrumen yang digunakan dalam penelitian ini adalah sebagai berikut: (1) lembar observasi, terdiri dari lembar observasi aktivitas guru dan lembar observasi aktivitas siswa. Observasi dilaksanakan selama proses pembelajaran berlangsung, (2) soal tes, menggunakan soal tes tulis dalam bentuk uraian yang disesuaikan dengan indikator kemampuan pemecahan masalah, dan (3) pedoman wawancara.

Analisis data dilakukan setelah pemberian tindakan. Analisis data dalam penelitian ini terdiri dari: (1) analisis data kualitatif, yaitu: reduksi data (data reduction), penyajian data (data display), dan penarikan kesimpulan atau verifikasi (conclusion drawing/verification), dan (2) analisis data kuantitatif, dianalisis dengan menggunakan rumus persentase ketuntasan belajar dan rata-rata kelas.

\section{HASIL PENELITIAN}

Hasil Observasi Aktivitas Kegiatan Guru Siklus I

\begin{tabular}{|c|c|c|c|c|c|c|c|}
\hline \multirow{3}{*}{ No } & \multirow{3}{*}{$\begin{array}{c}\text { Deskriptor } \\
\text { Kegiatan } \\
\text { Guru } \\
\end{array}$} & \multicolumn{3}{|c|}{ Pertemuan Pertama } & \multicolumn{3}{|c|}{ Pertemuan Kedua } \\
\hline & & \multirow{2}{*}{$\begin{array}{l}\text { Skor } \\
\text { Max }\end{array}$} & \multicolumn{2}{|c|}{ Skor Pengamat } & \multirow{2}{*}{$\begin{array}{l}\text { Skor } \\
\text { Max }\end{array}$} & \multicolumn{2}{|c|}{ Skor Pengamat } \\
\hline & & & 1 & 2 & & 1 & 2 \\
\hline 1 & Kegiatan awal & 20 & 16 & 17 & 20 & 17 & 18 \\
\hline 2 & Kegiatan inti & 30 & 26 & 27 & 30 & 28 & 29 \\
\hline 3 & Kegiatan akhir & 25 & 21 & 22 & 25 & 23 & 23 \\
\hline \multirow{2}{*}{\multicolumn{2}{|c|}{$\begin{array}{l}\text { Total skor } \\
\text { Persentase skor rata- } \\
\text { rata }\end{array}$}} & 75 & 63 & 66 & 75 & 68 & 70 \\
\hline & & $100 \%$ & $84 \%$ & $\mathbf{8 8 \%}$ & $100 \%$ & $90,66 \%$ & $93,33 \%$ \\
\hline \multicolumn{2}{|c|}{ Taraf keberhasilan } & $\begin{array}{c}\text { Sangat } \\
\text { Baik }\end{array}$ & $\begin{array}{c}\text { Sangat } \\
\text { Baik }\end{array}$ & $\begin{array}{c}\text { Sangat } \\
\text { Baik }\end{array}$ & $\begin{array}{c}\text { Sangat } \\
\text { Baik }\end{array}$ & $\begin{array}{c}\text { Sangat } \\
\text { Baik }\end{array}$ & $\begin{array}{c}\text { Sangat } \\
\text { Baik }\end{array}$ \\
\hline \multicolumn{2}{|c|}{$\begin{array}{l}\text { Rata-rata Skor } \\
\text { Pengamat } 1 \text { dan } 2\end{array}$} & \multicolumn{6}{|c|}{$\mathbf{8 8 , 9 7 \%}$} \\
\hline \multicolumn{2}{|c|}{ Taraf Keberhasilan } & \multicolumn{6}{|c|}{ Sangat Baik } \\
\hline
\end{tabular}

$\underline{\text { Hasil Obsevasi Kegiatan Siswa Siklus I }}$

\begin{tabular}{|c|c|c|c|c|c|c|c|}
\hline \multirow{3}{*}{ No } & \multirow{3}{*}{$\begin{array}{c}\text { Deskriptor } \\
\text { Kegiatan } \\
\text { Siswa }\end{array}$} & \multicolumn{3}{|c|}{ Pertemuan Pertama } & \multicolumn{3}{|c|}{ Pertemuan Kedua } \\
\hline & & \multirow{2}{*}{$\begin{array}{l}\text { Skor } \\
\text { Max }\end{array}$} & \multicolumn{2}{|c|}{ Skor Pengamat } & \multirow{2}{*}{$\begin{array}{l}\text { Skor } \\
\text { Max }\end{array}$} & \multicolumn{2}{|c|}{ Skor Pengamat } \\
\hline & & & 1 & 2 & & 1 & 2 \\
\hline 1 & Kegiatan awal & 20 & 10 & 10 & 20 & 15 & 15 \\
\hline 2 & Kegiatan inti & 30 & 24 & 26 & 30 & 26 & 28 \\
\hline 3 & $\begin{array}{l}\text { Kegiatan } \\
\text { akhir }\end{array}$ & 25 & 20 & 22 & 25 & 21 & 22 \\
\hline \multirow{2}{*}{\multicolumn{2}{|c|}{$\begin{array}{l}\text { Total skor } \\
\text { Persentase skor rata- }\end{array}$}} & 75 & 54 & 58 & 75 & 62 & 65 \\
\hline & & $100 \%$ & $72 \%$ & $77,33 \%$ & $100 \%$ & $82,33 \%$ & $86,66 \%$ \\
\hline
\end{tabular}




\begin{tabular}{lccccc} 
Taraf keberhasilan & $\begin{array}{c}\text { Sangat } \\
\text { Baik }\end{array}$ & Baik & Baik $\begin{array}{c}\text { Sangat } \\
\text { Baik }\end{array}$ & $\begin{array}{c}\text { Sangat } \\
\text { Baik }\end{array}$ & $\begin{array}{c}\text { Sangat } \\
\text { Baik }\end{array}$ \\
$\begin{array}{l}\text { Rata-rata Skor } \\
\text { Pengamat 1 dan 2 }\end{array}$ & & & $79,55 \%$ & \\
Taraf Keberhasilan & & \multicolumn{4}{c}{ Baik } \\
\hline
\end{tabular}

Hasil Tes Akhir siklus I

\begin{tabular}{clc}
\hline No & \multicolumn{1}{c}{ Hasil Tes Akhir Siklus } & Jumlah \\
\hline 1 & Rata-rata & 73,55 \\
2 & Nilai tertinggi & 95 \\
3 & Nilai terendah & 32 \\
4 & Jumlah siswa yang tuntas & 15 \\
5 & Jumlah siswa yang tidak tuntas & 7 \\
6 & Persentase siswa tuntas (\%) & $68,18 \%$ \\
7 & Persentase siswa tidak tuntas $(\%)$ & $31,82 \%$ \\
\hline
\end{tabular}

Kriteria Keberhasilan Minimal

\begin{tabular}{clccc}
\hline No & Kriteria Keberhasilan & $\begin{array}{c}\text { Kriteria Keberhasilan } \\
\text { Minimal }\end{array}$ & $\begin{array}{c}\text { Taraf } \\
\text { Keberhasilan } \\
\text { Tindakan }\end{array}$ & Keterangan \\
\hline 1. & $\begin{array}{l}\text { Keterlaksanaan pembelajaran } \\
\text { oleh guru }\end{array}$ & $81 \%$ & $79,55 \%$ & $\begin{array}{c}\text { Sudah } \\
\text { memenuhi }\end{array}$ \\
\hline 2. & Kegiatan siswa & $81 \%$ & $67,86 \%$ & $\begin{array}{c}\text { Sudah } \\
\text { memenuhi }\end{array}$ \\
\hline 3. & $\begin{array}{l}\text { Ketuntasan hasil tes akhir } \\
\text { siklus I }\end{array}$ & $75 \%$ & $73,55 \%$ & Tidak tuntas \\
\hline 4. & $\begin{array}{l}\text { Respon siswa senang pada } \\
\text { hasil wawancara }\end{array}$ & $50 \%$ & $66,66 \%$ & $\begin{array}{c}\text { Sudah } \\
\text { memenuhi }\end{array}$ \\
\hline
\end{tabular}

Berdasarkan tabel di atas dapat diketahui bahwa dari keempat kriteria keberhasilan yang telah ditetapkan, ada satu kriteria yang tidak memenuhi tersebut.

$\underline{\text { Hasil Observasi Aktivitas Kegiatan Guru Siklus II }}$

\begin{tabular}{|c|c|c|c|c|c|c|c|}
\hline \multirow{3}{*}{ No } & \multirow{3}{*}{$\begin{array}{c}\text { Deskriptor } \\
\text { Kegiatan Guru }\end{array}$} & \multicolumn{3}{|c|}{ Pertemuan Pertama } & \multicolumn{3}{|c|}{ Pertemuan Kedua } \\
\hline & & \multirow{2}{*}{$\begin{array}{l}\text { Skor } \\
\text { Max }\end{array}$} & \multicolumn{2}{|c|}{ Skor Pengamat } & \multirow{2}{*}{$\begin{array}{l}\text { Skor } \\
\text { Max }\end{array}$} & \multicolumn{2}{|c|}{ Skor Pengamat } \\
\hline & & & 1 & 2 & & 1 & 2 \\
\hline 1 & Kegiatan awal & 20 & 19 & 19 & 20 & 19 & 19 \\
\hline 2 & Kegiatan inti & 30 & 27 & 28 & 30 & 28 & 29 \\
\hline 3 & Kegiatan akhir & 25 & 22 & 24 & 25 & 23 & 24 \\
\hline \multirow{2}{*}{\multicolumn{2}{|c|}{$\begin{array}{l}\text { Total skor } \\
\text { Persentase skor rata- } \\
\text { rata }\end{array}$}} & 75 & 68 & 71 & 75 & 70 & 72 \\
\hline & & $100 \%$ & $90,66 \%$ & $94,66 \%$ & $100 \%$ & $93,33 \%$ & $96 \%$ \\
\hline \multicolumn{2}{|c|}{ Taraf keberhasilan } & $\begin{array}{l}\text { Sangat } \\
\text { Baik }\end{array}$ & $\begin{array}{l}\text { Sangat } \\
\text { Baik }\end{array}$ & $\begin{array}{l}\text { Sangat } \\
\text { Baik }\end{array}$ & $\begin{array}{c}\text { Sangat } \\
\text { Baik }\end{array}$ & $\begin{array}{l}\text { Sangat } \\
\text { Baik }\end{array}$ & $\begin{array}{c}\text { Sangat } \\
\text { Baik }\end{array}$ \\
\hline \multicolumn{2}{|c|}{$\begin{array}{l}\text { Rata-rata Skor } \\
\text { Pengamat } 1 \text { dan } 2\end{array}$} & \multicolumn{6}{|c|}{$93,62 \%$} \\
\hline \multicolumn{2}{|c|}{ Taraf Keberhasilan } & \multicolumn{6}{|c|}{ Sangat Baik } \\
\hline
\end{tabular}


Hasil Obsevasi Kegiatan Siswa Siklus II

\begin{tabular}{|c|c|c|c|c|c|c|c|}
\hline \multirow{3}{*}{ No } & \multirow{3}{*}{$\begin{array}{l}\text { Deskriptor } \\
\text { Kegiatan Guru }\end{array}$} & \multicolumn{3}{|c|}{ Pertemuan Pertama } & \multicolumn{3}{|c|}{ Pertemuan Kedua } \\
\hline & & \multirow{2}{*}{$\begin{array}{l}\text { Skor } \\
\text { Max }\end{array}$} & \multicolumn{2}{|c|}{ Skor Pengamat } & \multirow[t]{2}{*}{$\begin{array}{l}\text { Skor } \\
\text { Max }\end{array}$} & \multicolumn{2}{|c|}{$\begin{array}{c}\text { Skor } \\
\text { Pengamat }\end{array}$} \\
\hline & & & 1 & 2 & & 1 & 2 \\
\hline 1 & Kegiatan awal & 20 & 13 & 13 & 20 & 16 & 16 \\
\hline 2 & Kegiatan inti & 30 & 26 & 27 & 30 & 28 & 29 \\
\hline 3 & Kegiatan akhir & 25 & 22 & 23 & 25 & 22 & 24 \\
\hline \multicolumn{2}{|c|}{ Total skor } & 75 & 61 & 63 & 75 & 66 & 69 \\
\hline \multicolumn{2}{|c|}{ Persentase skor rata-rata } & $100 \%$ & $81,33 \%$ & $84 \%$ & $100 \%$ & $88 \%$ & $92 \%$ \\
\hline \multicolumn{2}{|c|}{ Taraf keberhasilan } & $\begin{array}{l}\text { Sangat } \\
\text { Baik }\end{array}$ & $\begin{array}{l}\text { Sangat } \\
\text { Baik }\end{array}$ & $\begin{array}{l}\text { Sangat } \\
\text { Baik }\end{array}$ & $\begin{array}{c}\text { Sangat } \\
\text { Baik }\end{array}$ & $\begin{array}{l}\text { Sangat } \\
\text { Baik }\end{array}$ & $\begin{array}{c}\text { Sang } \\
\text { at } \\
\text { Baik }\end{array}$ \\
\hline \multicolumn{2}{|c|}{$\begin{array}{l}\text { Rata-rata Skor Pengamat } \\
1 \text { dan } 2\end{array}$} & \multicolumn{6}{|c|}{$86,32 \%$} \\
\hline \multicolumn{2}{|c|}{ Taraf Keberhasilan } & \multicolumn{6}{|c|}{ Sangat Baik } \\
\hline
\end{tabular}

Hasil Tes Akhir Siklus II

\begin{tabular}{clc}
\hline No & \multicolumn{1}{c}{ Hasil Tes Akhir Siklus } & Jumlah \\
\hline 1 & Rata-rata & 84,26 \\
2 & Nilai tertinggi & 98 \\
3 & Nilai terendah & 65 \\
4 & Jumlah siswa yang tuntas & 18 \\
5 & Jumlah siswa yang tidak tuntas & 4 \\
6 & Persentase siswa tuntasan $(\%)$ & $81,82 \%$ \\
7 & Persentase siswa tidak tuntas & $18,18 \%$ \\
\hline
\end{tabular}

$\underline{\text { Kriteria Keberhasilan Minimal }}$

\begin{tabular}{clccc}
\hline No & Kriteria Keberhasilan & $\begin{array}{c}\text { Kriteria Keberhasilan } \\
\text { Minimal }\end{array}$ & $\begin{array}{c}\text { Taraf } \\
\text { Keberhasilan } \\
\text { Tindakan }\end{array}$ & Keterangan \\
\hline 1. & $\begin{array}{l}\text { Keterlaksanaan pembelajaran } \\
\text { oleh guru }\end{array}$ & $81 \%$ & $93,62 \%$ & $\begin{array}{c}\text { Sudah } \\
\text { memenuhi }\end{array}$ \\
\hline 2. & Kegiatan siswa & $81 \%$ & $86,32 \%$ & $\begin{array}{c}\text { Sudah } \\
\text { memenuhi }\end{array}$ \\
\hline 3. & $\begin{array}{l}\text { Ketuntasan hasil tes akhir } \\
\text { siklus II }\end{array}$ & $75 \%$ & $81,82 \%$ & $\begin{array}{c}\text { Sudah } \\
\text { memenuhi }\end{array}$ \\
\hline 4. & $\begin{array}{l}\text { Respon siswa senang pada } \\
\text { hasil wawancara }\end{array}$ & $50 \%$ & $83,33 \%$ & $\begin{array}{c}\text { Sudah } \\
\text { memenuhi }\end{array}$ \\
\hline
\end{tabular}

Berdasarkan tabel di atas dapat diketahui bahwa keempat aspek yang dinilai dalam penelitian ini seluruhnya telah mencapai kriteria keberhasilan minimal yang ditetapkan, yaitu keterlaksanaan strategi pembelajaran Every One is Teacher Here dengan persentase $93,62 \%$, kegiatan siswa dengan persentase $86,32 \%$, hasil tes akhir siklus mencapai $81,82 \%$, dan respon siswa dengan persentase $83,33 \%$. Hasil tersebut mengalami peningkatan dibandingkan hasil yang diperoleh pada siklus sebelumnya. Hal ini berarti bahwa kemampuan pemecahan matematika siswa telah meningkat.sehingga peneliti tidak perlu memberikan tindakan pada siklus berukutnya. 


\section{PEMBAHASAN}

Berdasarkan hasil wawancara sebelum pemberian tindakan, menunjukkan bahwa kemampuan pemecahan masalah siswa kelas VII tergolong rendah.

Berdasarkan kondisi di atas, maka peneliti menerapkan strategi pembelajaran Every One is Teacher Here dengan materi perbandingan.

Hasil lembar observasi aktivitas guru yang dilakukan oleh observer I dan observer II pada siklus I mencapai persentase keberhasilan 88,97\% dengan taraf keberhasilan dapat dikategorikan cukup baik, dan pada siklus II persentase keberhasilannya mengalami peningkatan menjadi 93,62\% dengan taraf keberhasilan dapat dikategorikan sangat baik.

Hasil lembar observasi aktivitas siswa yang dilakukan oleh observer I dan observer II pada siklus I mencapai persentase keberhasilan 79,55\% dengan taraf keberhasilan dapat dikategorikan cukup baik. Sedangkan pada siklus II persentase keberhasilannya mengalami peningkatan menjadi 86,32\% dengan taraf keberhasilan dapat dikategorikan baik. Peningkatan yang terjadi pada aktivitas siswa sangat terlihat sekali terutama pada proses pembelajaran menggunakan strategi pembelajaran Every One is Teacher Here.

Dalam menerapkan strategi pembelajaran Every One is Teacher Here, kemampuan pemecahan masalah siswa dapat meningkat. Hal ini dapat dilhat dari persentase ketuntasan hasil tes akhir siklus II yaitu $81,82 \%$ yang mengalami peningkatan dibanding persentase ketuntasan dan rata-rata kelas hasil tes akhir siklus I yaitu $68,18 \%$. Persentase ketuntasan yang ditetapkan, yaitu siswa mendapat nilai tes $\geq \geq$ 75\%. Persentase ketuntasan ini sudah mengalami peningkatan dari siklus I ke siklus II

Berdasarkan hasil analisis data diperoleh informasi bahwa terjadi peningkatan kemampuan pemecahan masalah siswa. Peningkatan tersebut antara lain dapat dilihat dari hasil tes akhir siklus I dan II. Di mana setiap butir soal yang digunakan pada setiap tes akhir siklus telah disesuaikan dengan indikator-indikator pemecahan masalah. Pemecahan masalah matematika siswa terhadap indikator ini didapatkan dari hasil jawaban soal tes akhir siklus

Dari uraian di atas, dapat disimpulkan strategi pembelajaran Every One is Teacher Here merupakan salah satu bentuk inovasi perbaikan kualitas pembelajaran matematika yang bertujuan untuk membantu siswa dalam meningkatkan pemecahan masalah matematika siswa pada materi perbandingan. Sehingga dapat disimpulkan bahwa pada penelitian ini, penerapan strategi pembelajaran Every One is Teacher Here untuk meningkatkan kemampuan pemecahan masalah materi perbandingan pada siswa kelas VII SMP Islam Fatahillah Singosari tahun pelajaran 2017/2018.

\section{SIMPULAN DAN SARAN}

Berdasarkan hasil penelitian dan serangkaian kegiatan tindakan pembelajaran dalam penelitian ini dapat disimpulkan bahwa penerapan strategi pembelajaran Every One is Teacher Here dapat meningkatkan kemampuan pemecahan masalah materi perbandingan pada siswa kelas VII SMP Islam Fatahillah Singosari tahun pelajaran 2017/2018.

Berdasarkan paparan data dan pembahasan, peneliti menyarankan kepada berbagai pihak, sebagai berikut:

1) Bagi Sekolah 
Bagi pihak sekolah disarankan untuk dapat memanfaatkan hasil penelitian ini untuk tercipta proses pembelajaran yang lebih aktif dan mampu meningkatkan kualitas pembelajaran.

2) Bagi Guru Bidang Studi Matematika

Bagi guru disarankan untuk mengembangkan strategi pembelajaran Every One is Teacher Here untuk meningkatkan kemampuan pemecahan masalah peserta didik. Namun strategi pembelajaran ini akan lebih bermanfaat untuk apabila guru menyesuaikan dengan karakteristik peserta didikdan materi yang disampaikan, agar memberikan inovasi baru dalam dunia pendidikan khususnya dalam pembelajaran dikelas untuk meningkatkan kemampuan pemecahan masalah peserta didik.

3) Bagi Peserta Didik

Bagi peserta didik hendaknya lebih giat belajar, bersifat aktif dalam proses pembelajaran, dan perbanyak latihan soalyang berbasis pemecahan masalah sehingga ketika mengerjakan soal tidak merasa kesulitan.

4) Bagi Peneliti Selanjutnya

Peneliti selanjutnya perlu mengkaji lebih mendalam tentang penerapan strategi pembelajaran Every One is Teacher Here dan meneliti lebih luas hal-hal yang mempengaruhi kemampuan pemecahan masalah peserta didik rendah agar hasil penelitian lebih maksimal.

\section{DAFTAR RUJUKAN}

Ariana, M. Desi dan Candiasa, AAIN Marhaennni. 2014. Pengaruh Implementasi dalam Pembelajaran Matematika Terhadap Kemampuan Pemecahan Masalah dengan Pengendalian Kemampuan Penalaran Abstrak. e-Journal Program Pascasarjana Universitas Pendidikan Ganesha, Volume 4 Tahun 2014

Nirmalitasari, Octa S. 2010. Profil Kemampuan Siswa dalam Memecahkan Masalah Matematika Berbentuk Open-Start pada Materi Bangun Datar. Jurusan Matematika Fakultas Matematika dan llmu Pengetahuan Alam Universitas Negri Surabaya.

Silberman, Melvin L. 2009. Cara Belajar Siswa Aktif. Bandung: Nuansa.

Sodiq. 2001. Strategi Belajar Mengajar. Jakarta: Universitas Terbuka.

Sudjana, Nana. 2009. Penilaian Hasil Proses Belajar Mengajar. Bandung: PT. Remaja Rosdakarya. 